\title{
Effects of feed probiotics on serum biochemistry and carcass characteristics of tropically bred exotic turkey
}

\author{
*Florence O. Oke, ${ }^{1}$ Gbolabo O. Onasanya, ${ }^{1}$ Ayodeji O. Adedire, ${ }^{2}$ \\ Oluwatosin O. Oduguwa ${ }^{3}$, Samuel O. Obadire ${ }^{4}$, Adekoya O. Osofowora ${ }^{3}$ \\ 1 Department of Animal Science, Federal University Dutse, Jigawa, Nigeria. \\ 2Department of Agriculture, Wesley University of Science and Technology, Ondo, Nigeria. \\ 3Department of Animal Nutrition, Federal University of Agriculture, Abeokuta, Nigeria. \\ 4Central laboratory, Federal Medical Centre, Birnin-kudu, Jigawa, Nigeria.
}

\begin{abstract}
This study was conducted to examine the effect of feed probiotics substituents in serum biochemistry and carcass characteristics of tropically bred exotic turkey. A total of 80 British united turkey (BUT) were assigned to 4 dietary treatments consisting of 4 supplemental levels of equal mixtures of RoxazymeG2 ${ }^{\mathbb{B}}$ at 200 ppm, $250 \mathrm{ppm}, 300 \mathrm{ppm}$ and $350 \mathrm{ppm}$. The polynomial contrast (linear and quadratic) was applied to determine the effect of inclusion of varying mixtures of enzyme and yeast supplementations using SPSS 1999. At starter phase (5-8 weeks), turkeys fed diet containing combination of 200 ppm enzyme and yeast recorded highest $(P<$ $0.05)$ PCV, Hb, WBC, RBC and glucose values. AST and serum uric acid values were highest $(P<0.05)$ for turkeys fed diet containing combination of 350 ppm enzyme and yeast. At grower phase (9-12 weeks), the values of WBC reduced significantly $(P<0.05)$ with increased combination of enzyme and yeast levels in the diet whereas $R B C$ recorded higher values. Turkeys fed diet containing combination of 200 ppm enzyme and yeast recorded a significantly $(P<0.05)$ high values of total serum protein and serum globulin relative to other combination levels. At finisher phase (13-16 weeks), birds on 350 ppm combined supplementation of enzyme and yeast recorded a significantly $(P<0.05)$ higher PCV HB, ALT and WBC compared to other treatments. The value for uric acid was significantly $(P<0.05)$ elevated in birds fed 200 ppm and 300 ppm enzyme and yeast combination. There was no significant $(P>0.05)$ effect of enzyme and yeast supplementation on live weight, dressing percentage, weights of head, neck, drum stick, thigh, breast, lungs, liver, heart, kidney, spleen, gizzard, proventriculus, crop and abdominal fat except back weight and wing weight that were significantly $(P<0.05)$ affected by dietary treatment. In conclusion, inclusion of feed additives in MSP diet such as enzymes and yeast is a good measure in enhancing serum biochemistry and production performance of exotic turkey bred in the humid tropics.
\end{abstract}

Key words: Blood parameters, carcass performance, roxazyme $G 2{ }^{\circledR}$ yeast, and MSP.

\section{Introduction}

One of the major constraints challenging poultry industry in Nigeria and other developing countries is the inadequate supply of conventional feed ingredients. It has therefore become imperative to find alternatives that are cheap and have no deleterious effect on poultry performance. Sorghum sprout is an example of agroindustrial by-product which could be used as an alternative feed ingredient.

Sorghum spp (Guinea corn) had replaced barley as a raw material in confectionery and brewering industry in many tropical countries (Banjoko, 1992). Malt is extracted from germinated sorghum seeds and the residue consists of sorghum shoots and roots. These residues are collectively referred to as malted sorghum sprouts (MSP). This MSP has a lot of prospects as a livestock feed but its usefulness is limited by its tannin content and non-starch polysaccharides (Elkin et al., 1995). Therefore, there is need for supplementation with probiotics which can enhance poultry performance.

Non-antibiotic growth promoters, such as organic acids and probiotics are increasingly being included in animal nutrition (Windisch et al., 2008). Gong et al. (2002) posited that probiotics are healthy bacteria, fungi or other beneficial microbes meant to inhabit the gastrointestinal tract of both humans and animals towards enhanced health, feed efficiency and production function. Probiotics are viable single or mixed cultures of micro-organisms that when given to animals, they beneficially affect the host by improving the properties of the indigenous microflora (Kyriakis et al., 1999 and Lee et al., 2008). The positive effects of probiotics on animals can result from its direct nutritional effect, where they act as bio-regulators of the intestinal microflora thus reinforcing the host's natural defense mechanisms.

Furthermore, addition of live yeast to livestock ration has been shown to enhance the nutritive quality of feed and production performance of animals (Martin et al., 1989; Glade and Sist, 1998). Studies on both humans and animals on the ability of probiotics to change the types and numbers of gut microflora and feed utilization have been reported (Endo et al., 1999; Roberfoid, 2007 and Saulnier, 2007). In this wise, probiotics are used to 
get rid of stress induced abnormalities in the gastrointestinal tract, thus normalizing and restoring gut activity (Kutlu et al., 2001). Some reports (Midilli and Tuncer, 2001 and Jin et al., 1998) revealed that additional benefits are obtainable by the supplementation of broiler diets with probiotics as feed additives. In a bid to address this challenge, concerted efforts have been made to incorporate anti-microbials and other natural products such as yeast and enzyme in animal feeds. This study therefore, intends to determine the effects of RoxazymeG $2^{\circledR}$ and yeast as a dietary probiotic sources on turkey serum biochemistry and carcass traits of tropically bred exotic turkey.

\subsection{Enzyme and yeast}

\section{Materials and method}

The commercial enzyme used in this study was a blend of multi-enzymes consisting of endo $-1,4-\beta$ - xylanase (EC 3.2.1.8), endo - 1, 3 (4) - $\beta$ - glucanase (EC 3.2.1.6) and endo - 1, $4-\beta$ - glucanase (EC 3.2.1.4) produced by Trichoderma reesei and bakers' yeast (Saccharomyces cerevisiae).

\subsection{Experimental birds and Management}

This study was carried out at the Poultry unit of the Teaching and Research Farm, Federal University of Agriculture, Abeokuta, Nigeria $\left(7^{\circ} 10^{\prime} \mathrm{N}\right.$ and $\left.3^{\circ} 2^{\prime} \mathrm{E}\right)$. Eighty day old male British United turkeys (BUT) were purchased from a reputable commercial hatchery. The poults were brooded intensively for 1-28 days preexperimental period in deep litter housing system during which the birds were fed together with pre-starter turkey ration (Table 1). During brooding, temperature was controlled at $34.5^{\circ} \mathrm{C}$ for the first 0 to 2 days and then gradually reduced by $2^{\circ} \mathrm{C}$ per week to a final ambient temperature of $27^{\circ} \mathrm{C}$ at the last week of brooding. Feed and clean water were supplied ad libitum. The birds were reared intensively on deep litter system. Required vaccination program and medication schedule were adhered to religiously.

\subsection{Dietary treatments}

At day 28, eighty male turkeys of similar weights were selected and assigned on weight equalization basis to four dietary treatments having Malted sorghum sprout (MSP) based diets supplemented with combination of varying levels $(200,250,300$ and $350 \mathrm{ppm})$ of Roxazyme $\mathrm{G}$ and baker's yeast (Saccharomyces cerevisiae) at ratio 1:1 levels for 28-56 days (starter phase), 56-84 days (grower phase) and 84-132days (Finisher phase) (Table 1). Each treatment group consisted of 20 turkeys replicated four times with 5 birds each.

\subsection{Serum bio-chemistry}

Blood samples were collected from 4 randomly selected turkeys per treatment ( 1 turkey/pen) at 56th and 84th day of the study to determine the blood serum chemistry. Blood collections were done through brachial vein puncture into vacuum tubes containing anticoagulants to obtain blood serum. Blood samples were immediately centrifuged at (1200 for $15 \mathrm{~min}$ ) for separation of plasma. Aliquots of plasma were taken according to requirements of test and were refrigerated at $-20^{\circ} \mathrm{C}$ for further analysis. The total serum protein, albumin, globulin, serum creatinine and serum uric acid concentration were analysed according to Jain (1986). Serum enzymes; alanine amino transaminase (ALT) and aspartate amino transferase (AST)) were analysed using the commercial kits (Qualigens India. Pvt. Ltd., Catalogue number 72201-04). The serum cholesterol was estimated using the enzymatic colorimetric methods (according to the manufacturer's manual) using using Randox ${ }^{\mathrm{R}}$ diagnostic cholesterol kit.

\subsection{Carcass Measurements}

At the end of the study, two birds whose weights were nearest to the average weight of birds in each replicate were selected, slaughtered, defeathered and eviscerated. The live weights of the birds were taken prior to slaughtering and the dressed weight was also recorded. The head, neck, breast, back, thigh, drumstick, shank were weighed and recorded, the spleen, kidney, lungs, gizzard, liver, heart, abdominal fat, proventriculus were also weighed using a sensitive digital electronic pocket scale. The weights were expressed as percentage of live weights.

\subsection{Statistical analysis}

Data obtained were analyzed using Polynomial contrast (linear and quadratic) using SPSS (1999) to determine the trends (linear and quadratic) inclusion of feed additives (enzyme and yeast). A probability $(\mathrm{P}<$ 0.05 ) was considered to be statistically significant. Means were separated using Duncan multiple range test.

\section{Results}

Effect of supplementation of varying dosage/mixtures of additives (enzyme and yeast) on haematological measurements of turkey poults fed basal diets containing $100 \mathrm{~g} / \mathrm{kg}$ MSP based diets for 28-56d (Table 2). The 
results revealed no significant effect $(\mathrm{P}>0.05)$ on ALT values. The PCV, Hb, WBC, RBC, glucose, albumin, globulin, STP decreased significantly $(\mathrm{P}<0.05)$ as inclusion of additives increases. Above 200ppm dietary combination of enzyme + yeast, $\mathrm{PCV}, \mathrm{Hb}, \mathrm{WBC}$ and $\mathrm{RBC}$ of the turkeys recorded lower values. However, turkeys fed diet containing combinations of $350 \mathrm{ppm}$ enzyme and yeast recorded highest AST and uric acid values. The serum uric acid values significantly $(\mathrm{P}<0.05)$ increased for turkeys fed diet containing $200 \mathrm{ppm}$ and 350ppm enzyme and yeast. Birds fed diet containing combination of $200 \mathrm{ppm}$ enzyme and yeast had significantly $(\mathrm{P}<0.05)$ high glucose and TSP values relative to other combinations. The effect of various combinations of enzyme and yeast supplementation levels on blood parameters of growing turkeys is presented in Table 2 (56-84days). The results showed no significant effect $(\mathrm{P}>0.05)$ on $\mathrm{PCV}$ and $\mathrm{Hb}$ values. The values of WBC reduced significantly $(\mathrm{P}<0.05)$ with increased combinations of enzyme and yeast. Relative to this, turkeys fed diet containing combinations of $250 \mathrm{ppm}, 300 \mathrm{ppm}$ and $350 \mathrm{ppm}$ enzyme and yeast recorded significantly $(\mathrm{P}<0.05)$ higher $\mathrm{RBC}$ values.

Turkeys fed diet containing combinations of 200 ppm enzyme and yeast recorded a significantly ( $\mathrm{P}<$ $0.05)$ high values of total serum protein, globulin and serum globulin relative to other combination levels. Significantly $(\mathrm{P}<0.05)$ higher values of AST were obtained for turkeys fed diet containing combinations of 200 ppm and $250 \mathrm{ppm}$ enzyme and yeast. Turkeys fed diet containing combinations of $350 \mathrm{ppm}$ enzyme and yeast recorded the least significant $(\mathrm{P}<0.05)$ AST values. ALT values showed significance $(\mathrm{P}<0.05)$ with no regular pattern. Dietary combinations of enzyme and yeast at $350 \mathrm{ppm}$ recorded a significantly $(\mathrm{P}<0.05)$ high serum uric acid concentration followed by $200 \mathrm{ppm}$ and $250 \mathrm{ppm}$ while dietary combinations of $300 \mathrm{ppm}$ enzyme and yeast resulted in the least serum uric acid concentration. Turkeys fed diet containing combinations of 250 ppm enzyme and yeast had a higher significant $(\mathrm{P}<0.05)$ serum creatinine values. Those fed diet containing mixtures of $200 \mathrm{ppm}$ enzyme and yeast recorded the least serum creatinine values. Glucose values ranged from $168 \mathrm{mg} / \mathrm{dl}$ for birds fed $350 \mathrm{ppm}$ to $130 \mathrm{mg} / \mathrm{dl}$ in birds fed mixtures of $300 \mathrm{ppm}$ enzyme and yeast.

The results of finishing turkey showed that all the blood parameters measured were significantly $(\mathrm{P}<$ 0.05 ) affected by the treatment imposed (Table 2). Birds on 350 PPM supplementation recorded the highest significant $(\mathrm{P}<0.05)$. PCV and HB values and were closely followed by birds on $200 \mathrm{ppm}$ and $250 \mathrm{ppm}$ while the least value was recorded for birds fed $300 \mathrm{ppm}$. Birds fed $350 \mathrm{ppm}$ recorded superior RBC values which were statistically similar with birds on $250 \mathrm{ppm}$, while the least $\mathrm{RBC}$ values were recorded for $200 \mathrm{ppm}$ and 300 ppm which were statistically similar. The WBC did not follow a particular pattern but birds on $350 \mathrm{ppm}$ recorded the highest significant $(\mathrm{P}<0.05) \mathrm{WBC}$ values while the least values were recorded for birds on 200 $\mathrm{ppm}$. The result revealed that turkey fed $200 \mathrm{ppm}$ and $350 \mathrm{ppm}$ had a significantly $(\mathrm{P}<0.05)$ higher total serum protein and albumin. Birds fed $200 \mathrm{ppm}, 300 \mathrm{ppm}$ and $350 \mathrm{ppm}$ were statistically similar but were significantly $(\mathrm{P}<0.05)$ higher than those fed $250 \mathrm{ppm}$ for AST. The highest ALT value of $8.00 \mathrm{iu} / 1$ was recorded when birds were offered $350 \mathrm{ppm}$, while the least statistically similar values were recorded for birds fed $200 \mathrm{ppm}, 250 \mathrm{ppm}$ and $300 \mathrm{ppm}$. However, the values for uric acid were elevated significantly $(\mathrm{P}<0.05)$ when birds were fed 200 ppm and $300 \mathrm{ppm}$, closely followed were birds on $250 \mathrm{ppm}$, while the least value was recorded for birds on 350 ppm supplementation.

Table 1: Gross composition of pre-starter (1-28d), starter (28-56d) grower (56-84d) and finisher (84-124d) diets and chemical composition of malted sorghum sprout (MSP)

\begin{tabular}{|c|c|c|c|c|c|}
\hline \multirow[b]{2}{*}{ Ingredients } & \multirow{2}{*}{$\begin{array}{l}\text { Pre-starter } \\
28 d) \text { diets }\end{array}$} & \multicolumn{3}{|c|}{ *MSP basal diets } & \multirow{2}{*}{$\begin{array}{l}\text { Chemical } \\
\text { Compositio } \\
\mathrm{n} \text { of MSP }\end{array}$} \\
\hline & & $\begin{array}{l}\text { Starter } \\
(28-56 \mathrm{~d})\end{array}$ & $\begin{array}{l}\text { Grower (56- } \\
84 d)\end{array}$ & $\begin{array}{l}\text { Finisher } \\
\text { (84-124d) }\end{array}$ & \\
\hline Maize & 430 & 425 & 505 & 560 & \\
\hline Soybean meal & 412 & 240 & 180 & 135 & \\
\hline Full fat soybean & - & 100 & 80 & 80 & \\
\hline Fish meal & 80 & 80 & 60 & 40 & \\
\hline Vegetable oil & - & - & 20 & 30 & \\
\hline MSP & - & 100 & 100 & 100 & \\
\hline Bone meal & 45 & 30 & 30 & 30 & \\
\hline Oyster shell & 20 & 14 & 14 & 14 & \\
\hline Lysine & 1 & 1.5 & 1.5 & 1.5 & \\
\hline Methionine & 4 & 2 & 2 & 2 & \\
\hline Premix $\dagger$ & 5 & 5 & 5 & 5.0 & \\
\hline Salt & 2.5 & 2.5 & 2.5 & 2.5 & \\
\hline Total & 1000 & 1000 & 1000 & 1000 & \\
\hline \multicolumn{6}{|c|}{ Chemical composition } \\
\hline Dry matter $(\mathrm{g} / \mathrm{kg})$ & 900.5 & 911.1 & 901 & 911 & 912 \\
\hline $\mathrm{ME}(\mathrm{MJ} / \mathrm{kg}) \ddagger$ & 11.93 & 12.27 & 12.75 & 13.21 & 11.69 \\
\hline
\end{tabular}


Effect of Feed Probiotics in serum biochemistry and carcass characteristics of tropically bred ....

\begin{tabular}{llllll}
\hline Crude protein $(\mathrm{g} / \mathrm{kg})$ & 281.9 & 263.6 & 223.2 & 194.5 & 163.7 \\
Ether extract $(\mathrm{g} / \mathrm{kg})$ & 37.6 & 53.0 & 48.8 & 47.7 & 38.2 \\
Crude fibre $(\mathrm{g} / \mathrm{kg})$ & 30 & 35.1 & 32.4 & 31.1 & 107.5 \\
Calcium $(\mathrm{g} / \mathrm{kg})$ & 21.6 & 15.6 & 15.0 & 14.5 & 9.2 \\
Phosphorus $(\mathrm{g} / \mathrm{kg})$ & 8.6 & 6.7 & 6.0 & 5.9 & 11.1 \\
Lysine $(\mathrm{g} / \mathrm{kg})+$ & 19.1 & 18.6 & 15 & 12.8 & - \\
Methionine $(\mathrm{g} / \mathrm{kg}) \dagger$ & 8.8 & 6.8 & 6.8 & 5.5 & - \\
NDF $(\mathrm{g} / \mathrm{kg})$ & & & & 217 \\
ADF $(\mathrm{g} / \mathrm{kg})$ & & & & 147 \\
ADL $(\mathrm{g} / \mathrm{kg})$ & & & & 103 \\
Gross energy $(\mathrm{MJ} / \mathrm{kg})$ & & & & 3.9 \\
HCN $(\mathrm{mg} / \mathrm{kg})$ & & & & 0.09 \\
Tannin $(\mathrm{mg} / \mathrm{kg})$ & & & & \\
\hline
\end{tabular}

Table 2: Effect of supplementation of varying dosage of mixtures of additives (enzyme and yeast) on haematological measurements of turkey poults fed basal diets containing $100 \mathrm{~g} / \mathrm{kg} \mathrm{MSP}$ based diets.

\begin{tabular}{|c|c|c|c|c|c|c|c|}
\hline \multirow{2}{*}{$\begin{array}{l}\text { Starter phase } \\
\text { Parameters }\end{array}$} & \multicolumn{4}{|c|}{ Enzyme and Yeast Levels (mg/kg) } & \multirow[b]{2}{*}{ SEM } & \multicolumn{2}{|c|}{ P value } \\
\hline & $\begin{array}{l}200 \\
\text { ppm }\end{array}$ & $\begin{array}{l}\text { 250 } \\
\text { ppm }\end{array}$ & $\begin{array}{l}\text { 300 } \\
\text { ppm }\end{array}$ & $\begin{array}{l}350 \\
\text { ppm }\end{array}$ & & $\mathbf{L}$ & $\mathbf{Q}$ \\
\hline $\begin{array}{l}\text { Packed cell volume } \\
(\%)\end{array}$ & $40.25^{\mathrm{a}}$ & $37.25^{\mathrm{b}}$ & $32.25^{\mathrm{bc}}$ & $35.75^{\mathrm{c}}$ & 0.47 & 0.000 & 0.000 \\
\hline Haemoglobin (g/l) & $13.43^{\mathrm{a}}$ & $12.40^{\mathrm{b}}$ & $12.08^{\mathrm{bc}}$ & $11.93^{\mathrm{c}}$ & 0.16 & 0.000 & 0.000 \\
\hline $\begin{array}{l}\text { White blood cell } \\
\left(\times 10^{9} / \mathrm{L}\right)\end{array}$ & $189.25^{\mathrm{a}}$ & $159.50^{\mathrm{c}}$ & $160.75^{\mathrm{c}}$ & $180.00^{\mathrm{b}}$ & 3.30 & 0.387 & 0.000 \\
\hline $\begin{array}{l}\text { Red blood cell } \\
\left(\times 10^{12} / \mathrm{L}\right)\end{array}$ & $204.75^{\mathrm{a}}$ & $143.75^{\mathrm{b}}$ & $133.25^{\mathrm{b}}$ & $141.50^{\mathrm{b}}$ & 7.59 & 0.001 & 0.000 \\
\hline Glucose $(\mathrm{mg} / \mathrm{dl})$ & $183.75^{\mathrm{a}}$ & $164.20^{\mathrm{c}}$ & $172.30^{\mathrm{b}}$ & $159.53^{\mathrm{d}}$ & 2.42 & 0.000 & 0.002 \\
\hline $\begin{array}{l}\text { Total serum protein } \\
(\mathrm{g} / \mathrm{dl})\end{array}$ & $43.13^{\mathrm{a}}$ & $40.35^{\mathrm{ab}}$ & $39.15^{\mathrm{b}}$ & $39.23^{\mathrm{b}}$ & 0.51 & 0.001 & 0.001 \\
\hline Albumin $(g / l)$ & $17.83^{\mathrm{a}}$ & $16.80^{\mathrm{b}}$ & $17.33^{\mathrm{ab}}$ & $17.10^{\mathrm{ab}}$ & 0.14 & 0.207 & 0.165 \\
\hline Globulin $(\mathrm{g} / \mathrm{L})$ & $25.30^{\mathrm{a}}$ & $23.53^{\mathrm{ab}}$ & $21.83^{\mathrm{b}}$ & $22.13^{\mathrm{b}}$ & 0.48 & 0.004 & 0.006 \\
\hline AST (iu/L) & $67.25^{\mathrm{b}}$ & $59.00^{\mathrm{b}}$ & $67.00^{\mathrm{b}}$ & $79.25^{\mathrm{a}}$ & 2.15 & 0.016 & 0.000 \\
\hline $\mathrm{ALT}(\mathrm{iu} / \mathrm{L})$ & 6.25 & 5.50 & 5.50 & 10.50 & 1.00 & 0.162 & 0.127 \\
\hline Uric acid (mg/dl) & $2.13^{\mathrm{a}}$ & $1.85^{\mathrm{b}}$ & $1.40^{\mathrm{c}}$ & $2.03^{\mathrm{a}}$ & 0.07 & 0.269 & 0.000 \\
\hline Creatinine $(\mathrm{mg} / \mathrm{dl})$ & $1.05^{\mathrm{c}}$ & $2.43^{\mathrm{a}}$ & $1.58^{\mathrm{b}}$ & $1.70^{\mathrm{b}}$ & 0.13 & 0.356 & 0.018 \\
\hline \multicolumn{8}{|l|}{ Grower Phase } \\
\hline $\begin{array}{l}\text { Packed cell volume } \\
(\%)\end{array}$ & 43.25 & 44.00 & 4300 & 44.75 & 0.28 & 0.172 & 0.272 \\
\hline Haemoglobin (g/l) & 14.43 & 14.70 & 14.333 & 14.93 & 0.09 & 0.193 & 0.305 \\
\hline $\begin{array}{l}\text { White blood cell } \\
\left(\times 10^{9} / \mathrm{L}\right)\end{array}$ & $238.25^{\mathrm{a}}$ & $144.00^{\mathrm{b}}$ & $111.00^{\mathrm{d}}$ & $121.00^{\mathrm{c}}$ & 13.06 & 0.000 & 0.000 \\
\hline $\begin{array}{l}\text { Red blood cell } \\
\left(\times 10^{12} / \mathrm{L}\right)\end{array}$ & $193.50^{\mathrm{b}}$ & $198.00^{\mathrm{ab}}$ & $197.50^{\mathrm{ab}}$ & $205.25^{\mathrm{a}}$ & 1.51 & 0.005 & 0.019 \\
\hline Glucose (mg/dl) & $152.88^{\mathrm{c}}$ & $162.75^{\mathrm{b}}$ & $130.00^{\mathrm{d}}$ & $168.00^{\mathrm{a}}$ & 3.76 & 0.721 & 0.016 \\
\hline Total protein $(\mathrm{g} / \mathrm{dl})$ & $45.91^{\mathrm{a}}$ & $39.80^{c}$ & $38.85^{\mathrm{d}}$ & $41.10^{\mathrm{b}}$ & 0.70 & 0.009 & 0.000 \\
\hline Albumin $(\mathrm{g} / \mathrm{l})$ & $19.78^{\mathrm{a}}$ & $18.40^{\mathrm{bc}}$ & $17.93^{\mathrm{c}}$ & $18.50^{\mathrm{b}}$ & 0.19 & 0.005 & 0.000 \\
\hline Globulin $(\mathrm{g} / \mathrm{L})$ & $26.13^{\mathrm{a}}$ & $21.40^{\mathrm{c}}$ & $20.93^{c}$ & $22.60 \mathrm{~b}$ & 0.54 & 0.015 & 0.000 \\
\hline AST (iu/L) & $21.00^{\mathrm{a}}$ & $21.00^{\mathrm{a}}$ & $18.00^{\mathrm{b}}$ & $12.00^{\mathrm{c}}$ & 0.97 & 0.000 & 0.000 \\
\hline $\operatorname{ALT}(\mathrm{iu} / \mathrm{L})$ & $7.00^{\mathrm{c}}$ & $10.05^{\mathrm{b}}$ & $38.50^{\mathrm{a}}$ & $7.00^{\mathrm{c}}$ & 3.44 & 0.373 & 0.015 \\
\hline Uric acid (mg/dl) & $2.40^{\mathrm{b}}$ & $2.13^{\mathrm{c}}$ & $1.50^{\mathrm{d}}$ & $2.78^{\mathrm{a}}$ & 0.12 & 0.658 & 0.000 \\
\hline Creatinine $(\mathrm{mg} / \mathrm{dl})$ & $1.03^{\mathrm{c}}$ & $2.50^{\mathrm{a}}$ & $1.88^{\mathrm{b}}$ & $1.83^{\mathrm{b}}$ & 0.14 & 0.154 & 0.001 \\
\hline \multicolumn{8}{|l|}{ Finisher phase } \\
\hline $\begin{array}{l}\text { Packed cell volume } \\
(\%)\end{array}$ & $46.75^{\mathrm{ab}}$ & $46.25^{\mathrm{ab}}$ & $44.25^{\mathrm{b}}$ & $48.50^{\mathrm{a}}$ & 0.52 & 0.001 & 0.042 \\
\hline Haemoglobin (g/l) & $15.58^{\mathrm{ab}}$ & $15.43^{\mathrm{ab}}$ & $14.75^{\mathrm{b}}$ & $16.15^{\mathrm{a}}$ & 0.17 & 0.507 & 0.044 \\
\hline $\begin{array}{l}\text { White blood cell } \\
\left(\times 10^{9} / \mathrm{L}\right)\end{array}$ & $136.25^{\mathrm{d}}$ & $158.50^{\mathrm{b}}$ & $147.50^{\mathrm{c}}$ & $179.75^{\mathrm{a}}$ & 4.26 & 0.000 & 0.001 \\
\hline $\begin{array}{l}\text { Red blood cell } \\
\left(\times 10^{12} / \mathrm{L}\right)\end{array}$ & $165.50^{\mathrm{bc}}$ & $178.75^{\mathrm{ab}}$ & $157.50^{c}$ & $184.00^{\mathrm{a}}$ & 3.20 & 0.244 & 0.004 \\
\hline
\end{tabular}


Effect of Feed Probiotics in serum biochemistry and carcass characteristics of tropically bred ....

\begin{tabular}{llllllll}
\hline Glucose $(\mathrm{mg} / \mathrm{dl})$ & $203.63^{\mathrm{a}}$ & $161.15^{\mathrm{c}}$ & $173.25^{\mathrm{b}}$ & $159.58^{\mathrm{c}}$ & 4.62 & 0.001 & 0.000 \\
Total protein $(\mathrm{g} / \mathrm{dl})$ & $53.38^{\mathrm{a}}$ & $43.80^{\mathrm{b}}$ & $45.35^{\mathrm{b}}$ & $49.55^{\mathrm{ab}}$ & 1.25 & 0.391 & 0.005 \\
Albumin $(\mathrm{g} / \mathrm{l})$ & $20.40^{\mathrm{a}}$ & $16.33^{\mathrm{b}}$ & $17.70^{\mathrm{b}}$ & $20.20^{\mathrm{a}}$ & 0.51 & 0.871 & 0.000 \\
Globulin $(\mathrm{g} / \mathrm{L})$ & $32.98 \mathrm{a}$ & $27.45 \mathrm{c}$ & $27.65 \mathrm{c}$ & $29.35 \mathrm{~b}$ & 0.83 & 0.157 & 0.020 \\
AST $(\mathrm{iu} / \mathrm{L})$ & $67.25^{\mathrm{ab}}$ & $63.25^{\mathrm{b}}$ & $79.25^{\mathrm{a}}$ & $76.00^{\mathrm{ab}}$ & 2.19 & 0.025 & 0.090 \\
ALT $(\mathrm{iu} / \mathrm{L})$ & $4.00^{\mathrm{b}}$ & $4.00^{\mathrm{b}}$ & $4.00^{\mathrm{b}}$ & $8.00^{\mathrm{a}}$ & 0.45 & 0.000 & 0.000 \\
Uric acid $(\mathrm{mg} / \mathrm{dl})$ & $3.73^{\mathrm{a}}$ & $3.18^{\mathrm{a}}$ & $3.93^{\mathrm{a}}$ & $2.78^{\mathrm{c}}$ & 0.12 & 0.045 & 0.053 \\
Creatinine $(\mathrm{mg} / \mathrm{dl})$ & $4.63^{\mathrm{b}}$ & $3.88^{\mathrm{c}}$ & $3.95^{\mathrm{c}}$ & $4.93^{\mathrm{a}}$ & 0.12 & 0.366 & 0.000 \\
\hline \multicolumn{7}{l}{} \\
the same row having different superscripts are significantly different $(\mathrm{P}<0.05)$
\end{tabular}

${ }^{\text {abc }}$ Means on the same row having different superscripts are significantly different $(\mathrm{P}<0.05)$

Table 3. Effect of supplementation of varying dosage of mixtures of additives (enzyme and yeast) on carcass traits of turkey fed basal diets containing $100 \mathrm{~g} / \mathrm{kg}$ MSP based diets.

\begin{tabular}{|c|c|c|c|c|c|c|c|}
\hline \multirow[b]{2}{*}{ Parameters } & \multicolumn{4}{|c|}{ Enzyme and Yeast Levels (mg/kg) } & \multirow[b]{2}{*}{ SEM } & \multicolumn{2}{|c|}{ P value } \\
\hline & 200ppm & 250ppm & 300ppm & 350ppm & & $\mathbf{L}$ & $\mathbf{Q}$ \\
\hline \multicolumn{8}{|l|}{ Carcass traits } \\
\hline Live weight $(\mathrm{g})$ & 8175.00 & 8775.00 & 8500.00 & 8875.00 & 169.12 & 0.240 & 0.488 \\
\hline Carcass weight (g) & 6408.38 & 7032.29 & 6686.1 & 6981.08 & 97.86 & 0.110 & 0.241 \\
\hline $\begin{array}{l}\text { Dressing percentage } \\
(\%)\end{array}$ & $\begin{array}{l}0408.58 \\
78.39\end{array}$ & 80.14 & $\begin{array}{l}0080.1 \\
78.84\end{array}$ & $\begin{array}{l}0901.08 \\
78.66\end{array}$ & 0.75 & 0.944 & $\begin{array}{l}0.241 \\
0.832\end{array}$ \\
\hline \multicolumn{8}{|l|}{ Cut parts $(\%$ of $L W)$} \\
\hline Head & 1.84 & 2.30 & 2.24 & 1.83 & 0.11 & 0.927 & 0.162 \\
\hline Neck & 4.96 & 6.09 & 5.68 & 5.87 & 0.22 & 0.249 & 0.297 \\
\hline Shank & $2.90^{\mathrm{b}}$ & $3.69^{\mathrm{a}}$ & $3.53^{\mathrm{ab}}$ & $3.65^{\mathrm{ab}}$ & 0.11 & 0.037 & 0.030 \\
\hline Drum stick & 11.16 & 12.24 & 11.31 & 11.94 & 0.17 & 0.367 & 0.551 \\
\hline Back & $16.20^{\mathrm{a}}$ & $14.74^{\mathrm{ab}}$ & $13.89^{\mathrm{b}}$ & $14.90^{\mathrm{ab}}$ & 0.32 & 0.102 & 0.029 \\
\hline Wings & $9.79^{\mathrm{b}}$ & $11.67^{\mathrm{a}}$ & $11.87^{\mathrm{a}}$ & $11.48^{\mathrm{a}}$ & 0.28 & 0.028 & 0.004 \\
\hline Thighs & 12.23 & 12.98 & 11.84 & 12.67 & 0.17 & 0.920 & 0.989 \\
\hline Breast & 25.52 & 24.51 & 24.57 & 24.03 & 0.28 & 0.078 & 0.204 \\
\hline \multicolumn{8}{|l|}{$\begin{array}{l}\text { Organs weight }(\% \text { of } \\
\text { LW) }\end{array}$} \\
\hline Lungs & 0.35 & 0.47 & 0.38 & 0.38 & 0.02 & 0.913 & 0.293 \\
\hline Heart & 0.32 & 0.39 & 0.33 & 0.36 & 0.01 & 0.460 & 0.420 \\
\hline Liver & 1.50 & 1.39 & 1.37 & 1.38 & 0.03 & 0.161 & 0.239 \\
\hline Kidney & 0.32 & 0.44 & 0.33 & 0.35 & 0.02 & 0.941 & 0.534 \\
\hline Spleen & 0.10 & 0.88 & 0.08 & 0.07 & 0.01 & 0.228 & 0.496 \\
\hline Gizzard & 3.07 & 2.87 & 2.93 & 2.83 & 0.06 & 0.207 & 0.429 \\
\hline Proventiculus & 0.22 & 0.24 & 0.25 & 0.23 & 0.01 & 0.550 & 0.228 \\
\hline Crop & 0.34 & 0.36 & 0.28 & 0.34 & 0.02 & 0.624 & 0.734 \\
\hline Abdominal fat & 0 & 0 & 0 & 0 & 0 & 0 & 0 \\
\hline
\end{tabular}

${ }_{a b c}$ Means on the same row having different superscripts are significantly different $(\mathrm{P}<0.05)$

\section{Discussion}

The highest values of PCV, Hb, RBC, glucose, TSP, albumin and globulin were recorded at the starter phase and finisher phase following the inclusion of the lowest dosage of enzyme and yeast supplementation $(200 \mathrm{ppm})$. However, TSP, Albumin and Globulin were highest at lower dosage of enzyme and yeast supplementation at the grower phase. This implies that poults fed diet containing 200ppm mixtures of enzyme + yeast had higher blood plasma. This finding in total serum protein (TSP) corroborrated Serrano et al. (2008) who found that TSP is applicable in the monitoring of body condition and nutritional status of Iberian wild goats (Capra pyrenaica). The PCV varied proportionately with the serum total protein (STP), thus suggesting that PCV is beneficial in assessing the protein status and possibly forecasting the degree of protein supplementation at different physiological states (Daramola et al., 2005). This also implies that poults fed diet containing 200ppm mixtures of enzyme + yeast had higher blood plasma protien. Futhermore, addition of enzyme and yeast supplementation could be responsible for increaseed total serum protein and glucose levels witnessed at both starter and finisher growth phase (Shereef and Al Dabbagh, 2009). The increased level of TSP concentrations observed both at starter phase (200 ppm of enzyme and yeast supplementation) and grower phase ( $>300 \mathrm{ppm}$ of enzyme and yeast supplementation) is an indication that the diet is rich in amino acid that led to increased TSP levels which invariably led to increase in serum albumin and globulin (Thrall et al., 2012).

Highest glucose value obtained for grower turkeys fed diet containing 350ppm enzyme and yeast supplementation showed sufficient energy for the bird thus sustaining physiological activities, physical activities 
and normal blood function (Adebisi, 1997). The higher levels of $\mathrm{Hb}$ and RBC obtained at the finisher phase with enzyme and yeast supplementation $(>300 \mathrm{ppm})$ suggested that the turkeys had high oxygen carrying capacity (Brij et al., 1977). This indicates that the nutritional profile of the diet was more enriched when supplemented with high level of enzyme and yeast additives. Nutrition was reported to influence the haemoglobin level of the blood (Udo, 1987). Pellet and Young (1980) confirmed that haemoglobin levels are positively correlated with protein quality and level in the diets.

The reduced serum enzymes (AST and ALT) obtained across all phases of growth could be associated with hepatho-protective effects of the yeast probiotics supplemented in the diet (Aluwong et al., 2013), any exaggerated increase in levels of serum enzymes (AST, ALT) could be an indication of liver damage and necrosis (Yalcin et al., 2012). In addition, reduced serum uric acid was recorded for finishing turkeys fed diets containing 350ppm enzyme and yeast supplementation informs efficient protein utilization by the turkeys. Kumta and Harper (1961) and Eggum (1970) reported a general fall of serum urea concentrations with time in nutritionally balanced amino acids based diets. Dietary inclusion of $350 \mathrm{ppm}$ dosage of enzyme and yeast supplementation recorded the highest WBC at the finisher phase. This increase suggested the introduction of antibodies into the systems of birds as they grow probably through feed ingredients or compromised management systems which could consequently trigger the production of WBC with a view to enhancing phagocysis and elevating immune respose mechanisms, white blood cells played prominent roles in disease resistance and immune response mechanisms especially with respect to the generation of antibodies and the process of phagocytes (Wintrobe, 1983).

However, the reduced values of WBC obtained for turkeys fed with diets containing $>200$ ppm enzyme and yeast additives at starter and grower phases could be due to the absence of foreign bodies which could have triggered or raised the leucocyte count at this phase of growth (Wintrobe, 1983). A very high serum creatinine levels obtained across all stages of experiment revealead the extent of muscle wastage occurring in a livestock animal. In respect of carcass characteristics, weights of head, neck, drumstick, thigh, breast, gizzard, proventriculus, crop and abdominal fat were not affected by increased dosage of enzyme and yeast supplementation. This implies that the inclusion of enzyme and yeast supplementation did not influence the parameters aforementioned. However, significantly higher shank and wing weights were obtained for turkeys fed diet containing combined dosage of ( $250 \mathrm{ppm}, 300 \mathrm{ppm}$ and $350 \mathrm{ppm})$ enzyme and yeast supplementation. Therefore, dietary inclusion of increased dosage of enzyme and yeast supplementation favoured higher production of shank and wing weight. Our findings agreed with the previous studies that inclusion of enzymes, synthetic amino acids and other feed additives/probiotics significantly influence some cut parts of poultry birds (Crouch et al., 2000).

The highest back weight was recorded with turkeys fed diet containing combined dosage of 200ppm enzyme and yeast supplementation. Similar trend was obtained in the values of back weight documented for turkeys fed diet containing combined dosage of $250 \mathrm{ppm}, 300 \mathrm{ppm}$ and $350 \mathrm{ppm}$ enzyme and yeast supplementation. Finally, increased inclusion of yeast and enzyme supplentation in our study showed no effect on weights of the organs examined.

In conclusion, the inclusion of feed additives such as enzyme and yeast in turkey nutrition profile plays a significant role in enhancing haematological and serum biochemical traits of exotic turkey bred under humid tropical condition with increased immune-capacity to withstand harsh tropical environment and that hematological and serum biochemical traits are good measures to assess health status and livestock productivity. Similarly, inclusion of feed additives such as enzyme and yeast in turkey nutrition enhances the tissue performance of wing weight, shank weight and back weight of tropically bred exotic turkeys.

\section{References}

[1]. Adebisi, A. O. (1997). Comparative effect of two sources of Saccharomyces cerevisiae supplement into a high fibre diet for starting pullets. M.Sc. Thesis, Department of Animal Science, University of Ibadan. pp. 126

[2]. Aluwong, T., Hassan, F. B., Raji, M. A., Kawu1, M. U., Dzenda, T. J. and Ayo, O. J. (2013). Effect of different levels of supplemental yeast on performance indices, serum enzymes and electrolytes of broiler chickens. African Journal of Biotechnology. Vol. 12(35), pp. 5480-5485. DOI: 10.5897/AJB12.2588.

[3]. Barrow, P. (1992). Probiotics for chickens. In: Probiotics, the Scientic Basis (Fuller, R., Ed.). Chapman and Hall, London. 225-257.

[4]. Banjoko, J. S. T. 1992. Industrial use of sorghum in Nigeria. Publication of ICRISAT on utilization of sorghum and millets. Pp 115116.

[5]. Brij, M. A., Horward, M. R. and Bhuran, V. V. (1977). Clinical biochemical and haematological value in normal experimental animals. Massan Publishing Co. U.S.A. F r Geflugelkunde, 54: 34-37.

[6]. Crouch, A. N., Lerner, S. P. and Karunakaran, D. (2000). Influence of feed quality in the brooding period of commercial turkeys and its subsequent effect on market performance. Poultry Science 79: $67-68$.

[7]. Duncan, D. B. (1955). Multiple Range and Multiple F-test Biometric. 11: 1-24

[8]. Eggum B. O. (1970). Protein quality of cassava leaf. British Journal of Nutr. 24: 761-768.

[9]. Elkin, R. G., Rogler, J. C. and Sulliven, T. W. 1995. Differential response of ducks and chicks to dietary Sorghum tannins. Journal of the Science of Food and Agriculture 57: 542-553

[10]. Endo, T., Nakano, M., Shimizu, S., Fukushima, M. and Miyoshi, S. (1999). Effect of a probiotic on the lipid metabolism of cocks fed on cholesterol-enriched diet. Bioscience, Biotec. Biochem. 63: 1569-1575. 
[11]. Gong, J., Forster, R. J., Yu, H. and Chambers, J. R., Wheat craft, R. Sabour, P. M. and Shu, C. (2002). Molecular analysis of bacterial populations in the ileum of broiler chickens and comparision with bacteria in the cecum, FEMS Microbiol. Ecol. 41: 171179 .

[12]. Glade, M. J. and Sist, M. O. (1998). Dietary yeast culture supplementation enhances urea recycling in equine large intestine. Nutr. Reprod. Int. 37: 11-17.

[13]. Jain, M. C. (1986). Schalon's Veterinary haematology. $6^{\text {th }}$ edition. Lea and Fabinger, Philadelphia. U.S.A. pp $178-207$.

[14]. Jin, L. Z., Ho, Y. W., Abdullah, N., Ali, M. A. and Jalaluddin, S. (1998). Effects of adherent lactobacillus cultures on growth, weight of organs and intestinal microflora and volatile fatty acids in broilers. Anim. Feed Sci. Tec. 70: 197-209.

[15]. Kutlu, H. R. and Görgülü M. (2001). The feed additive alternatives to antibiotic growing in poultry diets. Yem Magazin Dergisi. 27: 45-51.

[16]. Kumta, U. S. and Harper, A. E. (1961). Amino acid balance and imbalance. VII. Effects of dietary additions of amino acids on food intake and blood urea concentration of rats fed low-protein diets containing fibrin. Journal of Nutrition 74, $139-147$.

[17]. Kyriakis, S. C., Tsiloyiannis, V. K., Vlemmas, J., Sarris, K., Tsinas, A. C., Alexopoulos, C. and Janseqers, L. (1999). The effect of probiotic LSP 122 on the control of post-weaning diarrhoeas syndrome of piglets. Res. Vet. Sci. 67: 223-228.

[18]. Lee, N. K., Yun, C. W., Kim, S. W., Chang, H. I., Kang, C. W. and Paik, H. D. (2008). Screening of Lactobacilli derived from chicken feces and partial characterization of Lactobacillus acidophilus A12 as an animal probiotics. J. Microbiol. Biotechnol.18: 338-342.

[19]. Martin, S. A., Nisbet, B. J. and Dean, R. G. (1989). Influence of a commercial yeast supplement on the in vitro ruminal fermentation. Nutr. Reprod. Int. 40: 395-403.

[20]. Midilli, M and Tuncer, S. D. (2001). The effects of enzyme and probiotic supplementation to diets on broiler performance. Turk. J. Vet. Anim. Sci. 25: 895-903.

[21]. Muihead, S. (1992). Direct-feed products. In: Muihead, S. (Ed), Direct feed microbial enzyme and forage additive compendium. The Miller publishing coy. Minnetonka, M.N. pp. 45-207.

[22]. Mundow, H. and Bergner, H. (1986). Protein metabolism and Nutrition. European

[23]. Pellet, P. Z. and Young, N. P. (1980). Nutritional evaluation of protein feeds. United Nation Universal World Hunger Programme. Food and Nutrition bulletin. pp 154.

[24]. Roberfroid, M. (2007). Prebiotics: The concept revisited. J. Nutr. 137: 830.

[25]. Saulnier, D. M. (2007). Identification of prebiotic fructooligosaccharide metabolism in Lactobacillus plantarum WCFS1 through microarrays. Appl. Environ. Microbiol. 73: 1753.

[26]. Shareef, A. M. and Al-Dabbagh, A. S. A. (2009) Effect of probiotic (Saccharomyces cerevisiae) on performance of broiler chicks. Iraqi Journal of Veterinary Sciences, Vol. 23, Supplement (23-29) Proceedings of the 5th Scientific Conference, College of Veterinary Medicine, University of Mosul.

[27]. Serrano, E., Gonzalez, F.J., Granados, J.E., Moro, G., Fandos., P., Soriguer, R.C. and Perez, J.M. (2008) The use of total serum proteins and triglycerides For monitoring body condition in the Iberian wild Goat (Capra pyrenaica). Journal of zoo and wildlife medicine 39(4): 646-649.

[28]. SPSS. 1999. Statistical Package for Social Sciences. SPSS for Microsoft Windows Release 6.0 Users manual.

[29]. Thrall, M. A., Veiser, G., Allison, R. and Campbel, T. W. (2012). Veterinary Hematology and Clinical Chemistry. $2^{\text {nd }}$ Edition pp $60-90$.

[30]. Udo, H. (1987). Effect of cassava peels supplementation in swine ration on performance, haematology and serum metabolites in growing pigs. M.Sc. Thesis submitted to the Department of Animal Science, University of Ibadan. pp 112.

[31]. Windisch, W., Schedle, K., Plitzner, C. and Kroismayr, A. (2008). Use of phytogenic products as feed additives for swine and poultry. J. Anim. Sci. 86: 140-148.

[32]. Wintrobe, N. M. (1983). The size of haemoglobin content of erythrocytes. Method of determination and clinical application. Journal of laboratory and Clinical Medicine 17:87

[33]. Yalcin S, Yalcin S, Uzunoglu K, Duyum HM, Eltan O (2012). Effects of dietary yeast autolysate (Saccharomyces cerevisiae) and black cumin seed (Nigella sativa L.) on performance, egg traits, some blood characteristics and antibody production of laying hens. Livest. Sci. 145: 13-2023. 